\title{
Moufet's Theatrum Insectorum
}

When the great Swiss zoologist, Conrad Gessner, died on $13^{\text {th }}$ December 1565, he left behind him an unfinished book upon Entomology. The MS was sold to Thos. Penny, M. A. Cambridge who became a Prebendary of St Paul's Cathedral, London, but was dispossessed in 1577 for nonconformity.

Thomas Penny also acquired the notes on entomology which had been made by Edward Wotton, M. D. Oxford, who had died in 1555. He amalgamated the work of Gessner and Wotton and added further notes of his own before he died in 1589 .

Thomas Moffett or Moufet (the name is spelt in various ways), borne at London 1553, who became a M. A. of Trinity College, Cambridge, in 1576 and M. D. of Basle in 1578 acquired the MS after the death of Penny and completed the work and prepared it for publication before he died in 1604.

Moffett's heirs were unable to publish the MS and it was sold to Sir Thomas Mayerne, who, after keeping it lying by for some years, finally published it in 1634 as: "Insectorum sive minimorum animalium Theatrum olim ab Edoardo Wottono, Conrado Gesnero, Thomaque Pennio inchoatum: tandem Tho. Moufeti Londinatis opera sumptibusque maximis concinnatum, auctum, perfectum et ad vivum expressis iconibus supra quingenis illustratum ...» Londin. 1634.

Sir Thomas Mayerne was a Swiss physician, who rose te be the chief physician to the King of France. He was a Protestant and when France became uncomfortable for Protestants he removed to England where in due course he was appointed physician to King James I. At the time of the publication of the book he was one of the physicians to King Charles I.

The book is a sumptuous folio and most of the information given above is to be found on its title page. It is written in Latin and was never reprinted but an English translation by Topsell appeared in 1658.

\section{H. Malcolm Fraser (Pinner, England)}

